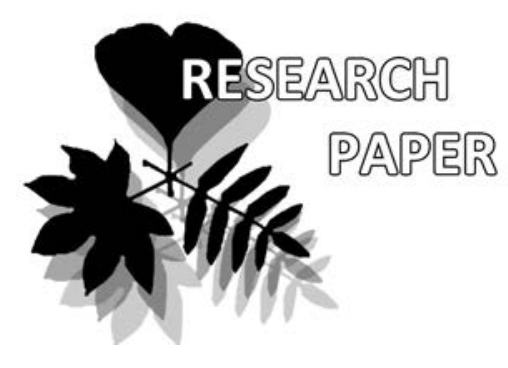

\title{
Mechanisms of seed dormancy in Cardiocrinum cordatum var. glehnii (Liliaceae)
}

\author{
Elena V. Andronova*, Oksana G. Butuzova \& Alla A. Torshilova
}

Elena V. Andronova*

e-mail: elena_andronova@binran.ru

Oksana G. Butuzova

e-mail: obutuzova@binran.ru

Alla A. Torshilova

e-mail: phoenix62@binran.ru

Komarov Botanical Institute RAS, Saint-Petersburg, Russia

* corresponding author

Manuscript received: 04.07.2019

Review completed: 07.10.2019

Accepted for publication: 10.10.2019

Published online: 12.10 .2019

\begin{abstract}
A B S T R A C T
Using integrated method of seed germination of Cardiocrinum cordatum (Thumb.) Makino var. glehnii (Fr. Schmidt) Hara (Liliaceae) under different temperature regimes and in vitro culture of isolated embryos, the presence of the physiological mechanism of inhibition (PhMI) of embryo postdevelopment and two PhMI of seed germination was proven. The PhMI of postdevelopment was established to be localized in the seed structures surrounding the embryo (firstly alive endosperm). It is overcome under the influence of the temperature factor, and probably the illumination. Embryo grew at $9-20^{\circ} \mathrm{C}$ due to cotyledon expansion. One of the PhMI of germination is localized in the embryo, and the other one in the seed structures. The removal of both mechanisms occurs under the influence of low temperatures stepwise. The root started to grow only after prolong cold stratification of the seeds with completely developed embryo. A detailed analysis of the results obtained manifested the temperature not to be the only factor in removing the $\mathrm{PhMI}$, but the duration of its exposure as well. If periods of different temperatures treatment alternate, the total duration of exposure to specific temperature matters.

K e y w o r d s : seed germination, embryo postdevelopment, morpho-physiological dormancy, embryo culture, Cardiocrinum, Liliaceaes
\end{abstract}

\section{P E 3 Ю M E}

Андронова Е.В., Бутузова О.Г., Торшилова А.А. Механизмы покоя семян у Cardiocrinum cordatum var. glebnii (Liliaceae). С использованием комб̆инированной методики проращивания семян Cardiocrinum cordatum (Thumb.) Makino var. glebnii (Fr. Schmidt) Hara (Liliaceae) при разных температурных режимах и культуры изолированных зародышей in vitro доказано наАичие физиологического механизма торможения (ФМТ) доразвития зароАыша и Авух механизмов ФМТ прорастания семян. Установлено, что ФМТ доразвития зародыша мокализован в окружающих зародыш структурах семени. Он преодолевается под Аействием температурного фактора, и вероятно, освещенности. Рост зародыша осушествляется при 9-20 ${ }^{\circ} \mathrm{C}$ за счет удАинения семядоли. ОАин из ФМТ прорастания находится в зародыше, а Аругой в структурах семени (возможно, в первую очередь, в энАосперме). Снятие обоих механизмов происходит под Аействием низких температур поэтапно. Зародышевый корень начинает расти только после Алительной холодной стратификации семян после окончания доразвития зародыша. Аетальный анализ полученных результатов показывает, что не только значение температуры явцяется фактором снятия ФМТ Аоразвития и прорастания, а Алительность ее воздействия. При этом важна суммарная продолжительность возАействия определенной температурой.

КАючевые слова: прорастание семян, рост зародыша внутри семени после Аиссеминации, доразвитие зародыша, морфофизиологический покой, культура зародыша, Cardiocrinum, Liliaceae
Biodiversity conservation is one of the priorities in the modern world. A catastrophic decrease in species and genetic diversity of plants is caused by the rapid and often irreversible destruction of ecosystems as a result of increasing human activities. These man-induced environmental changes can have a strong influence on the populations of rare plant species, the biology of which has a number of features developed in the course of their natural evolution. As a rule, a majority of rare wild plant species have a predominantly seed mode of reproduction, but at the same time they are characterized by difficult seed germination. Further, rare species may require a long period of time for dormancybreak and germination to occur, which is a part of their natural regeneration, but this can increase their vulnerability.

All the characteristics mentioned above could be applied to the rare species Cardiocrinum cordatum (Thumb.) Makino var. glehnii (Fr. Schmidt) Hara (Glen's lily), a perennial rhizomatous-bulbous plant, a relic of the tertiary flora. In Russia it grows only on the Kuril Islands and Sakhalin Island. The species is included in the Red Book of the Russian Federation (Barkalov 2008). Besides Russia, the species is common in Japan. 
The time from dissemination to the appearance of seedlings is very long: after dissemination (October), the seeds are in state of deep dormancy for almost a year. Post-dispersal development of the embryo occurs in the autumn of the year following the dissemination, and seed germination and seedling formation occur in spring of the second year after the dissemination (Kawano et al. 2004).

Two seed germination studies on C. cordatum var. glehnii, conducted in natural and experimental conditions are known (Dvorakovskaya 1977, Kondo et al. 2006). However the data from these experiments resulted in two opposite opinions on the kind of seed dormancy. The kind of seed dormancy for this species has been determined to be deep simple morpho-physiological (MPD) (Kondo et al. 2008, according to the classification Baskin \& Baskin 1998, 2004) and deep complex MPD (Nikolaeva et al. 1985, according to the data of Dvorakovskaya 1977). In our previous publication (Butuzova et al. 2019) based on more extended variants of temperature treatment on the seeds and using the culture of isolated embryos, we referred the seed dormancy of C. cordatum var. glehnii to a deep complex MPD, and considered the temperature and illumination to be the main factors of dormancy break.

However, the data we obtained go beyond only determining the type of dormancy and optimizing the regimes of seed germination. Therefore, the aim of this work was detailing the processes of embryo postdevelopment and germination in C. cordatum var. glehnii to understand nature of seed dormancy and mechanisms of its breaking.

\section{MATERIAL AND METHODS}

The technique was described in detail earlier (Butuzova et al. 2019). Here we present only the most important details of the experiments conducted.

Seeds of C. cordatum var. glehnii were collected from the plants introduced in the Leningrad region and stored for 2 years in a refrigerator. Seven variants of the experiment on temperature requirements to break dormancy and promote germination were used (Fig. 1, 2). The temperature of $18-20^{\circ} \mathrm{C}$ was considered to be high, $9-10^{\circ} \mathrm{C}-$ low, and $0-3^{\circ} \mathrm{C}-$ low positive.

During the course of the experiment, the length of the embryo, 10 seeds each, was measured every 2 weeks. In this case, the covers of the seed were not removed, because the contours of the embryo were clearly visible using the combined illumination (transmitted and reflected light). The measurements were made using a Stemy 2010 Zeiss stereoscopic microscope and the Image-Pro Insight 8.0 software package. Statistics were processed using Microsoft Exel. Data on the dynamics



Figure 1 Dynamics of post-dispersal growth of embryo in variants of the experiments without periods of prolong low temperature $\left(0-3^{\circ} \mathrm{C}\right)$ treatment of seeds. Arrows indicate the dates of the beginning of embryo postdevelopment in concrete variants of the experiment (after Butuzova et al. 2019, modified)

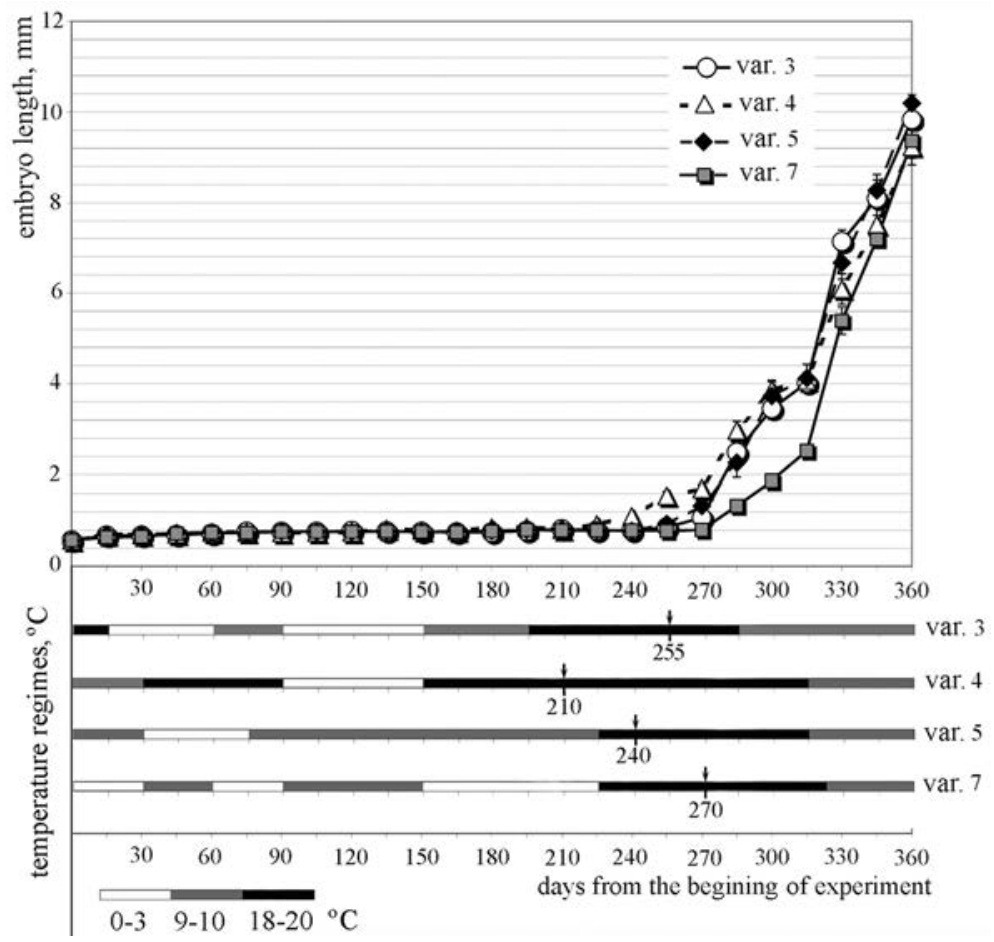

Figure 2 Dynamics of post-dispersal growth of embryo in variants of the experiments with periods of prolong low temperature $\left(0-3^{\circ} \mathrm{C}\right)$ treatment of seeds. Arrows indicate the dates of the beginning of embryo postdevelopment in concrete variants of the experiment (after Butuzova et al. 2019, modified)

of embryo length changes are presented in Figs 1 and 2, as average values with the standard deviation.

The embryos from a part of the seeds at the time of the experiment was started, as well as those from seeds at the time of completed embryo development - (360 days after the beginning of the experiment in variants $3,5,7)$ were isolated and planted in vitro. A modified nutrient medium 
Murashige and Skoog (Murashige \& Skoog 1962) with half concentrations of macro-and micro-salts was used for planting. The embryos were cultivated at a temperature of 23.0 $\pm 1.0^{\circ} \mathrm{C}$, and one part of the cultures was kept in a dark incubator and the other part exposed to continuous light from fluorescent lamps.

\section{RESULTS AND DISCUSSION}

The average embryo length in mature seeds at the time of dissemination is $0.57 \pm 0.02 \mathrm{~mm}$. It occupies $1 / 10$ of the length of the seed and is located in a special endosperm cavity. Growth of embryos in the different variants of the experiment began at different times from the beginning of the experiment. In variants $1,2,3,4,5,6$, and 7 , it was 225 , $150,255,210,240,210$ and 270 days, respectively, when the embryo began to grow (Butuzova et al. 2019).

Based on the results of our experiment (Butuzova et al. 2019) and literature data (Kondo et al. 2006), it can be concluded that the species studied possesses a long period after dissemination, when the embryo in the seed does not develop under any temperature conditions. This indicates the presence in this species of the physiological mechanism of inhibition of the embryo postdevelopment (PhMI postdevelopment) (Nikolaeva 1967, 1999). We use the term of physiological mechanism of inhibition as it possesses a specific location in certain seed structure unlike the physiological dormancy (PD) of the seed as a whole.

An experiment with isolated embryos at the time of dissemination, which began to grow immediately and completed development after 2 weeks, indicates that the PhMI of embryo postdevelopment is localized in the surrounding embryonic seed structures (firstly alive endosperm).

Nikolaeva $(1967,1999)$ paid special attention to the $\mathrm{PhMI}$ of embryo postdevelopment and took it into account in her classification. In Baskin \& Baskin classification the PhMI of embryo postdevelopment was not taken into consideration. Nikolaeva defined that the complex MPD is characterized by the presence of PhMI of embryo postdevelopment and indicated temperature regimes for it's removal $\left(0-10^{\circ} \mathrm{C}\right)$. Unlike complex, there is no PhMI of postdevelopment in a simple MPD. Temperature regimes for development proceeding could be the same at both levels of MPD. We emphasize that not the temperature diapason during embryo postdevelopment, but the presence of $\mathrm{PhMI}$ of postdevelopment, the factors of which are likely not limited by the temperature, is considered to be the most important criterion for determination of dormancy level.

We agree with the definition of seed dormancy in this species as deep, complex morpho-physiological. Nevertheless, we base our opinion not only on the temperature conditions for the removal of PhMI of postdevelopment but also on the fact of the presence of a long period of embryo dormancy before its growing started, which is not under the temperature control. This justifies a strong PhMI of postdevelopment. Therefore, Cardiocrinum is not considered on a par with species with simple PhMI of postdevelopment. According to Kondo et al. (2006) under natural conditions, the period when the embryo does not grow lasts 12 months. The length of this period in an experiment conducted by Japanese colleagues (Kondo et al. 2006) was only 3.5 months, i.e. it was shorter than in our experience (at least 5 months). This, apparently, may be due to several reasons. Firstly, the Japanese colleagues conducted an experiment on freshly harvested seeds, in contrast to the present study, where the seeds were kept in a refrigerator for 2 years. Secondly, seed germination in the experience of Japanese colleagues was influenced not by one, as in our experiment, but by two factors - temperature and light $\left(15 / 5^{\circ} \mathrm{C}\right.$, illumination 12 hours light / 12 hours darkness). Probably, not only temperature but also light is an important factor for overcoming PhMI of embryo postdevelopment in the species studied. Moreover, the seed coat and the endosperm of the study taxon are translucent. Furthermore, a more detailed analysis of the results manifests that not only the temperature value is referred to be a factor of PhMI postdevelopment removal but the duration of its exposure as well. So, PhMI of postdevelopment is removed faster with prolonged exposure (4 months) at $\mathrm{t}^{\circ} \mathrm{C} 18-20$ (variant 2) even if the period is divided into 2 ( 2 months each) with a period of low $\mathrm{t}^{\circ} \mathrm{C} \mathrm{0-3}$ (variant 4) (Figs 1, 2).

After 315-360 days the embryo reached its final size. In all variants of the experiment, an increase in the embryo length during the period of postdevelopment was mainly due to the growth of the cotyledon. However, with different temperature treatments, embryo growth was found to be unequally intensive. The most intensive growth of the cotyledon was observed in variant 1 .

The average length of the embryo when postdevelopment was completed ranged from $8.22 \pm 0.23$ to $10.67 \pm$ $0.58 \mathrm{~mm}$ depending on the variant of temperature treatment of the seeds. The embryo was curved-shaped and was differentiated into organs - a narrow cotyledon, a hypocotyl, an embryonal root and a shoot apex (Fig. 3A). The long, slightly curved cotyledon with an extended base was four times the length of the short hypocotyl-root axis. The shoot apex was located in the notch of the expanded base of the cotyledon. The embryo possessed a well distinguishable vascular system represented by procambium bundles of the central cylinder and cotyledon (Butuzova et al. 2019).

After completion of embryo postdevelopment, exposing part of the seeds from all variants of the experiment to low $\left(0-3^{\circ} \mathrm{C}\right)$ temperatures promoted germination. At higher and lower temperatures, germination was not observed. These data indicate that seed dormancy in C. cordatum var. glehnii is caused not only by PhMI of embryo postdevelopment but also by the physiological mechanism of inhibition germination (PhMI germination), which is removed after a long (5-6 months) exposure to low temperature. The final percentage of germinated seeds reached $90 \%$.

In our experience, 7 variants of temperature treatments were utilized (Figs 1, 2). Therewith, some of the variants included long-term treatment with low temperature, and others did not. In variants 3, 5, 7 there were several periods of low temperature treatment $\left(0-3{ }^{\circ} \mathrm{C}\right)$ between which there were periods of higher or lower temperatures ( $9-10$ or 18$20^{\circ} \mathrm{C}$ ). In total, periods of low temperature ranged from 1.5 to 4.5 months. In all cases, periods of low temperature preceded the beginning of embryo postdevelopment. 

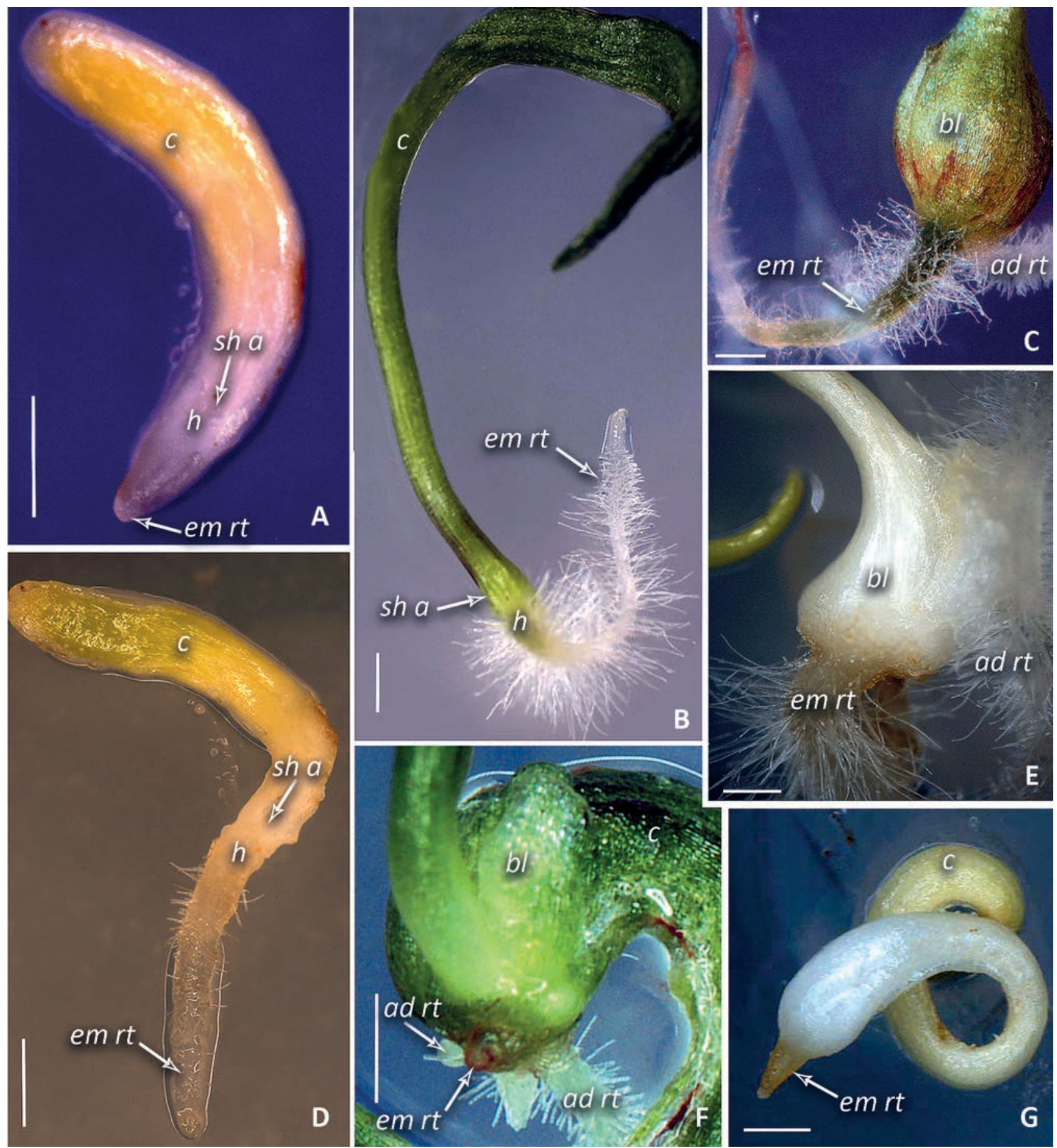

B
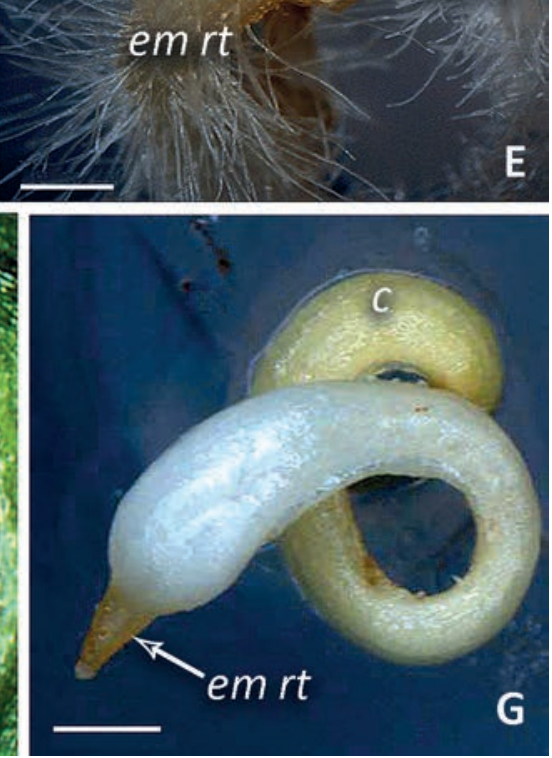

Figure 3 The structure of embryo isolated after postdevelopment completion at the time of planting on medium (A) and juvenile plants, developing in vitro culture in the light $(\mathrm{B}, \mathrm{C}, \mathrm{F})$ and in the darkness $(\mathrm{D}, \mathrm{E}, \mathrm{G})$. Plants on the 5 th $(\mathrm{B}, \mathrm{D})$ and 9 th $(\mathrm{C}, \mathrm{E})$ weeks of cultivation, obtained from the embryos after prolong cool stratification of seeds, the growth of embryonic root is observed; plant on the 7 th (F) and 10 th $(G)$ weeks of cultivation, obtained from the embryos without cool stratification of seeds, embryonic root is seen to be not developed. ad $\mathrm{rt}$ - advntive root, bl - bulb-like structure, c - cotyledon, em rt - embryonic root, h - hypocotyle, sh a - shoot apex. Scales: A, B, D - 2 mm; C, E, F - 4 mm; G - 1 mm (after Butuzova et al. 2019, modified)

Two important facts are noteworthy.

1. If in embryos isolated at the time of dissemination and at the time of postdevelopment completion but without prolonged cold treatment the embryonic root did not grow in culture in vitro, then in embryos isolated at the time of postdevelopment completion and given a cold treatment the embryonic root has developed in culture in vitro. These facts indicate the presence of inhibition mechanisms of embryonic root growth (PhMI germination) localized in the embryo itself.

2. If in the embryos isolated from the seeds that underwent early cold treatment before embryo development in vitro the embryonic root started growing, in embryos of the same seeds the embryonic root did not grow in the experiment on water, consequently, no germination was observed. This proves the presence of another mechanism of 
germination inhibition, localized not in the embryo, but in other structures of the seed.

Thus, a generalized analysis of the results obtained by combining two different methods indicates that there are two different PhMI of germination. One is located in the embryo itself, and the other one is in the seed structures surrounding the embryo. It was manifested that both mechanisms are removed during prolonged exposure to low temperature. However, it must be taken into consideration that low-temperature treatment should be carried out at certain periods of the experiment on germination of Cardiocrinum seeds, which differ for various parts of the seed.

$\mathrm{PhMI}$ of germination localized in the embryo and associated with inhibition of embryonic root growth is proposed to be removed under a long-term low-temperature treatment before embryo postdevelopment. This is a result from the data on cultivation of isolated embryos from variants 3 and 7 , where the growth of the embryonic root was observed, whereas in the embryos from variant 5 embryonic root growth did not occur at all (Fig. 3A). Obviously, in variant 5, the length of the cold stratification period was not long enough (1.5 months) comparing with variants 3 and 7. Apparently, 3.5 months of germinating seeds at $0-3^{\circ} \mathrm{C}$ is enough to remove the $\mathrm{PhMI}$ of germination localized in the root. In the temperature scheme of variants 3 and 7, there were not one, but several periods of low-temperature treatment lasting 1 to 2.5 months alternating with periods at another temperature, which equally resulted in the removal of the mechanism of embryonic root growth inhibition mechanism. The total length of the lowtemperature treatment period is believed to be sufficient to remove the PhMI of root growth localized in the embryo.

$\mathrm{PhMI}$ of germination localized in the seed structures surrounding the embryo, could be removed only under a long-term low-temperature treatment, which should be included in the experimental scheme just after 2 consecutive events have been completed: firstly, PhMI of the embryo postdevelopment should be removed, and secondly, the developmental period ought to be completed. Both of these periods occur at lower or higher temperatures $\left(9-20^{\circ} \mathrm{C}\right)$ and are probably stimulated by light. The periods of low-temperature treatment before embryo development did not stimulate the removal of PhMI germination localized in the structures of the seed. Nevertheless, as the results of the cultivation of isolated embryos from variants 3 and 7 showed, the mechanism of inhibition of embryonic root growth was removed, and it developed normally.

Based on our results, it can be concluded that the regulations of the mechanisms of inhibition or trigger of growth processes differ in various organs of the embryo. To trigger the growth in the cotyledon and in the hypocotyl of an embryo that has not passed the stage of postdevelopment, it is sufficient to remove the influence of the endosperm and / or seed covers. To start growth processes in the embryonic root, this is not enough. The trigger of growth in the embryonic root depends on the longevity of temperature factor influence and can be started both before the start of postdevelopment and after it.

For plants from variants 3 and 7 , there were differences in the morphogenesis of seedlings during their growth in the light vs. in the dark. After 4 weeks of cultivation in light, white adsorption hairs were formed on the root and the adjacent part of the hypocotyl (Fig. 3B), and after 5 weeks the hypocotyl and the base of the cotyledon began to thicken resulting in the formation of a bulb-like structure. By the end of the second month of cultivation, the bulblike structure was produced in the plants, at the base of which adventive roots were formed. By the beginning of the third month of cultivation in the light, the plants had a well-developed green leaf-like cotyledon and the first true leaf, a green bulb-like structure at the base of which numerous adventive roots developed (Fig. 3C).

During cultivation in the dark, the morphogenesis of plants with a developing embryonic root proceeded similarly; the difference was in a slower growth rate and the absence of green pigmentation in the cotyledon and bulb-like structure (Fig. 3D, E).

Thus, the growth of the embryonic root was observed both in the light and in the dark, but only in plants from the experimental variants 3 and 7 , where the seeds were subjected to prolonged cold treatment. These results indicate that the PhMI of germination in Cardiocrinum seeds is determined by the special state of the root apex, the removal inhibition of its growth occurs under the influence of the temperature $0-3^{\circ} \mathrm{C}$ but does not depend on illumination. As the results of investigation showed, hormonal treatment did not stimulate root growth (Kondo et al. 2006), and consequently, seed germination, which indicates the depth of dormancy (deep MPD).

In plants without a developing embryonal root from variant 5 , intensive growth of the cotyledon, a bulb-like structure and adventive roots was observed in the light. At the same time, the embryonic root remained in the form of brown rudiment during the entire cultivation period (Fig. 3F). During the cultivation of embryos without embryonal root in the darkness, the bulb-like structure and adventive roots were absent in the seedlings, only the cotyledon developed and the first leaf of the shoot apex was formed (Fig. 3G). Without transferring to the light, such seedlings perished.

Thus, the analysis of obtained data showed that the processes of embryo development and seed germination are controlled by various mechanisms localized in different parts of the seed. Hence, the PhMI of embryo postdevelopment does not occur in the embryo itself, but in other seed structures. Two PhMI of germination exist, one is in the embryo, and the other in the seed structures surrounding the embryo. The removal of all mechanisms occurs step by step. In vivo, the removal of seed dormancy happens sequentially in 3 stages (Fig. 4). It is important that the removal of PhMI germination from the seed structures but not from the embryo becomes possible only after embryo postdevelopment completion. In vivo, this occurs only at the second winter season. The PhMI germination localized in the embryo is considered to be removed in the first winter season. In experimental conditions, it is possible to use this fact for accelerating the process of seed germination and seedling growth because only one longterm cold stratification is required that has to be included 


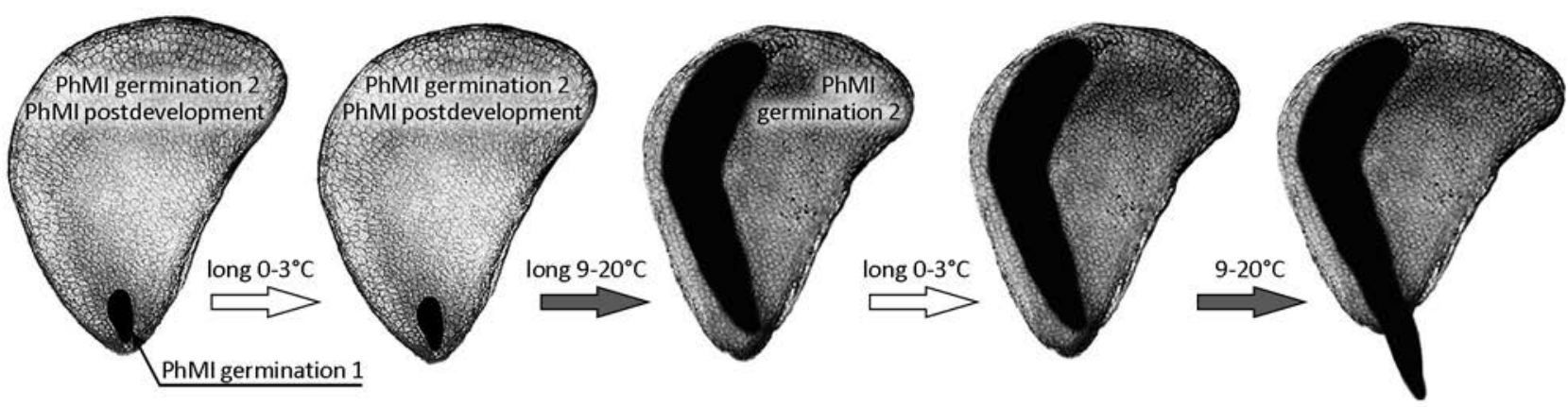

Figure 4 Scheme of PhMI germination removal in Cardiocrinum cordatum var. glebnii

in the scheme of experiment after the process of embryo postdevelopment is completed.

\section{ACKNOWLEDGEMENTS}

The present study was carried out within the framework of the institutional research project (no. AAAA-A18-118051590112-8) of the Komarov Botanical Institute of the Russian Academy of Sciences "The diversity of morphogenetic programs of plants reproductive structures development, natural and artificial models of their realization".

\section{LITERATURE CITED}

Barkalov, V.Yu. 2008. Cardiocrinum cordatum. In: Red data book of nature of the Russian Federation (plants and fungi). (Yu.P. Trutnev et al., ed.), pp. 316-317, Ministry of Natural Resources and Ecology of the Russian Federation and Rosprirodnadzor, Moscow (in Russian). [Баркацов В.Ю. 2008. Кардиокринум сердцевидный // Красная книга Российской Федерации (растения и грибы) / поА. ред. Ю.П. Трутнева и Ар. Министерство природных ресурсов и экологии РФ и Росприроднадзора. Москва. С. 316-317].

Baskin, J.M. \& C.C. Baskin 1998. Seeds: ecology, biogeography, and evolution of dormancy and germination. Academic Press, San Diego, California, USA, 666 pp.

Baskin, J.M. \& C.C. Baskin 2004. A classification system for seed dormancy. Seed Science Research 14:1-16.

Butuzova, O.G., A.A. Torshilova \& E.V. Andronova 2019. Seed dormancy in Cardiocrinum cordatum var. glebnii (Liliaceae) and ways of its overcoming. International Journal of Plant Reproductive Biology 11(1):51-57.

Dvorakovskaya, V.M. 1977. Temperature conditions of seed germination in Far East plants from Liliacae family. Byulleten' Glavnogo Botanicheskogo Sada Akademii Nauk SSSR
105:108-110 (in Russian). [Авораковская B.M. 1977. Температурные условия прорастания семян дальневосточных растений из сем. Liliaceae. // Бюлметень ГАавного Ботанического СаАа АН СССР. Вып.105. C. 108-110.]

Kawano, S., M. Ohara \& J. Masuda 2004. Cardiocrinum cordatum (Thunb.) Makino (Liliaceae). In: Life history monographs of Japanese plants. Spring plants, vol. 1(1). Hokkaido University Press, Sapporo, Japan, P. 49-56.

Kondo, T., Ch. Sato, J.M. Baskin \& C.C. Baskin 2006. Postdispersal embryo development, germination phenology, and seed dormancy in Cardiocrinum cordatum var. glebnii (Liliaceae s. str.) a perennial herb of the broadleaved deciduous forest in Japan. American Journal of Botany 93(6): 849-859.

Murashige, T. \& F. Skoog 1962. A revised medium for rapid growth and bioassays with tobacco tissue culture. Plant Physiology 15:473-497.

Nikolaeva, M.G. 1967. Physiology of deep seed dormancy. Nauka, Leningrad, 206 pp. (in Russian). [Николаева М.Г. 1977. Физиология глубокого покоя семян. А.: Наука. 206 с.].

Nikolaeva, M.G. 1999. Peculiarities of seed germination depended on phylogenetic position of plants and ecologogeographical conditions of their habitat. Fiziologia rastenii 46(3):432-437 (in Russian). [Николаева М.Г. 1999. Особенности прорастания семян в зависимости от фиАогенетического положения растений и эколого-географических условий их обитания // Физиология растений. Т. 46, № 3. С. 432-437].

Nikolaeva, M.G., M.V. Razumova \& V.N. Gladkova 1985. Reference book on dormant seed germination. Nauka, Leningrad, 347 pp. (in Russian.). [Николаева М.Г., Разумова М.В., ГАаАкова В.Н. 1985. Справочник по проращиванию покоящихся семян. $\Lambda .:$ Наука. 347 с.]. 